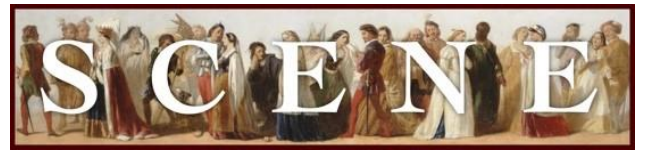

\title{
Henry the Fourth at the Barbican
}

\section{by Gretchen Minton. Written on 2015-01-09. Published in 2017 Issue 1.}

For the production: Henry IV Parts I and II (2014, Royal Shakespeare Company, UK). See production details at the end of the review.

After a successful RUN at the Royal Shakespeare Theater, Gregory Doran's productions of Henry the Fourth, Parts 1 and 2 re-opened at the Barbican in November. The plays were beautifully executed, designed, and costumed, with a clarity of presentation that is characteristic of Doran's directing. Part 1 opened in a church, with Henry (Jasper Britton) prostrate under a huge crucifix suspended from the ceiling. A song about Jerusalem (a repeated motif throughout the production) was chanted, and a Christ-like Richard the Second appeared on a platform above in order to emphasize the guilt that overshadowed Henry's reign. Despite the king's genuine desire to go to the Holy Land, a shift of mood quickly arose when Henry heard of the rebellion, then immediately threw his cape back to reveal chain mail and a sword at the ready, making it clear that this king is always expecting war. This gesture was repeated with the final lines of Part 2 when Prince John (Elliot Barnes-Worrell) showed the same readiness to go to war again, throwing back his cape and grasping for his sword. Between these two bookends, the productions of Henry IV presented a world in which the state is a powerful, cruel entity that consumes everyone for its own ends. That is a vision of history that does not shy away from the brutal nature of Medieval politics.

Such a focus had the intriguing side-effect of de-emphasizing Hal's autonomy. Alex Hassell portrayed the Prince with intelligence and charm. This fun-loving Hal emerged onto the stage half-naked from under the bed covers with not one, but two women. The Eastcheap scenes fully utilized the stage's two elevated platforms, multiple tables, and a trapdoor from which the tapster emerged, crowding the stage with merriment and showcasing Falstaff. Yet in the midst of this revelry, Hal appeared often distraught, or even angry. He drank heavily until his mind was clouded, no doubt in an attempt to suppress the inevitable fate of what he must become. At one point the end of his scene overlapped with the beginning of Hotspur's, and the prince saw his rival through a sort of drunken haze, haunted thoroughly by this vision which appeared against his will. When Hal and Falstaff rehearsed the imminent meeting with the king, Hal was light and happy until the drastic change between "I do" and "I will." In this interpretation, Hal 
was not voicing a choice, but instead an inevitability, and his horror at this moment of realization was palpable.

During the actual meeting with Henry, Hal attempted a genuine display of earnest boyish promises, but the king merely laughed at him. As a father, he was rough and angry, even physically abusive. He was not comforted by his eldest son's assurances, but only dismissed such language and demanded proof. Similarly, Henry was not proud, but instead annoyed by Hal when he offered the chivalric challenge to Hotspur before the battle of Shrewsbury. The moment when Hal saved Henry on the battlefield was the only time the king was impressed, for these were tangible actions befitting the warlike nature of his reign. The production perfectly illustrated the notion of the body politic: Hal had not saved his father, but the kingdom in the person of his father.

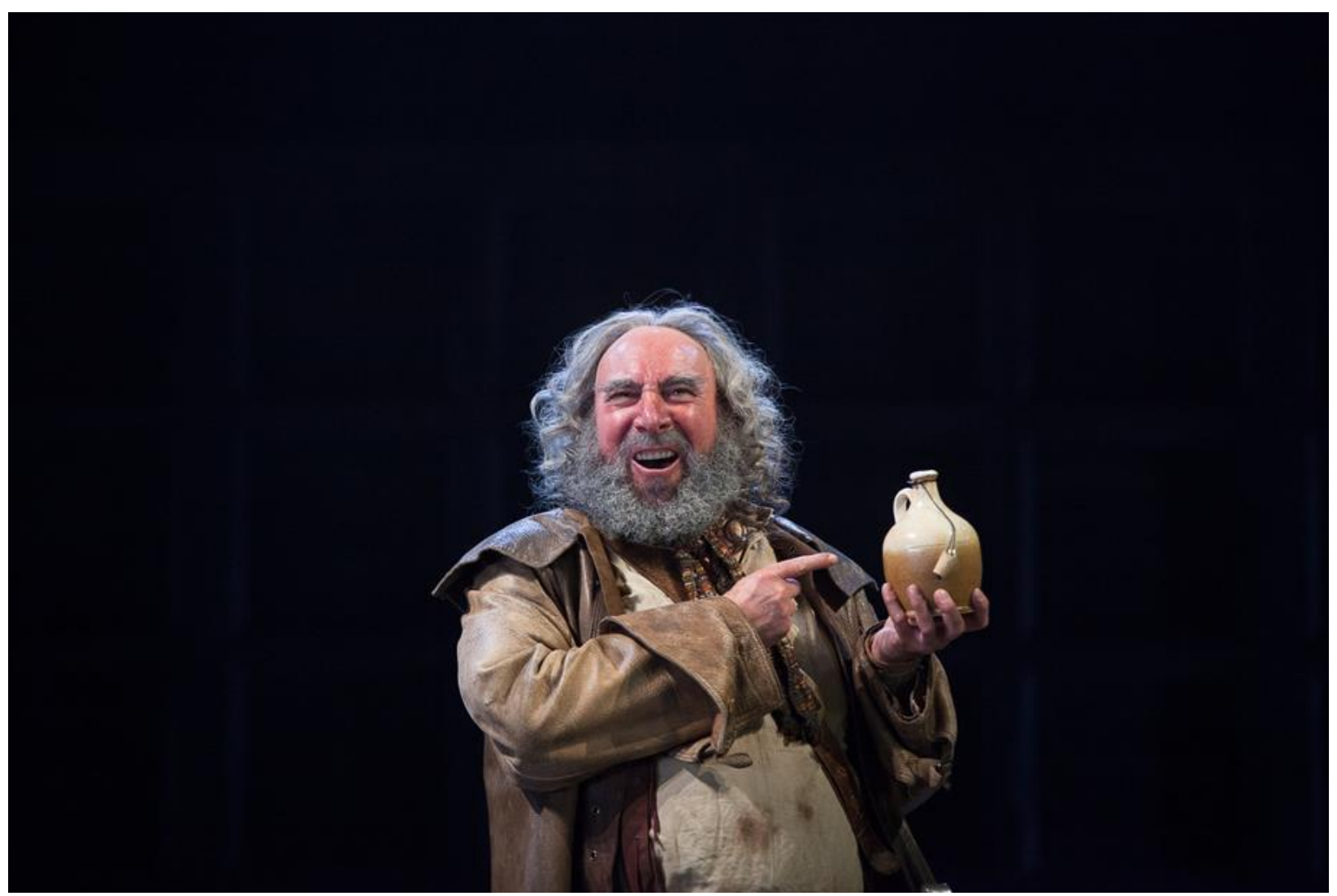

Figure 1: Anthony Sher as Sir John Falstaff in Henry IV Part 2. Photograph by Kwame Lestrade.

By the end of Part 1, much of the life and individuality had been taken out of Hal; throughout Part 2, therefore, he pursued a course of action that had a tendency to make him much more like his cold and efficient brother, John. His one attempt to play a trick on Falstaff fell painfully flat. Hal and Poins seemed like foolish fraternity boys who sought to re-live their glory days and found that all of the pranks no longer had any meaning. Henry showed occasional signs of 
having had a youthful personality and vitality, perhaps when he was known as Bolingbroke, but this has completely passed. Henry thus emerged as a fascinating study of a king who had long since lost his humanity because he had become the embodiment of the kingdom. Even when Henry was weeping and being weighed down by cares, he still did not seem as much a real person as a symbol of a diseased state. And as this abstraction, Henry overpowered his heir.

The Percy family echoed the same generational tension. Rather than being a strong independent force, Hotspur (Trevor White) seemed like a pawn of his father and uncle. They barked orders at him and even at one point abused him by tweaking his ear. Hotspur was thus jumpy, erratic, and insecure (tendencies that carried over into his exchanges with Lady Percy). While this behavior did illustrate the notion that the older generations had become cruel political instruments, the characterization caused a loss of depth to Hotspur, who did not seem a likely war hero or adequate foil to Hal. Hal seemed saddened by Hotspur's death, but given his characterization in Part 1, it was not clear why; Harry Percy was not a competing star so much as a damaged child. The position of Hal's foil thus largely fell to Prince John, whose continued menacing presence in Part 2 served as an uncomfortable reminder of what Hal would inevitably become.

The emphasis upon the state and politics at the expense of individuality naturally made for a grim focus. The great genius of this production, however, was the way in which this framework allowed for the magnificent vitality of Falstaff. Antony Sher's portrayal of the fat knight showed him as a unique individual in the midst of the political facelessness, reveling in life, carnivalesque disorder, and human community. Although he was large and had difficulty walking, the humor of this portrayal did not rest upon the physicality of the character, but instead upon the language. It became clear that Hal and others enjoyed Falstaff precisely because he was so smart and witty-a man who made every party much more enjoyable because of the unexpected phrases that tumbled off his tongue. His metaphors and his "if" clauses rang clearly, painting visual pictures that gave life and spirit to an otherwise gray world.

Therefore, when Falstaff became a naysayer to honor, it was easy to find him attractive, because it so compellingly voiced a resistance to the ideology that is used as a mechanism of power. Such a positive portrayal did, of course, have the unfortunate side-effect of whitewashing Falstaff's own ethically problematic behavior (e.g. robbing pilgrims, misusing the king's press, setting up poor soldiers as cannon fodder). Nonetheless, he and his world offered a muchneeded voice against the political machine. Especially in Part 2, Falstaff's life force was supported by those around him. The scenes with Mistress Quickly and Doll Tearsheet, as well as those with Justices Silence and Shallow, echoed the example of joyous individuality set by Falstaff. Again, the scenes were most successful when the language became the source of 
humor, rather than over-wrought physical business (as, unfortunately, characterized the scene with Pistol).

The most successful moment of showing the contrast between the state and its people occurred in Part 2's Act 3, scene 1, when Mistress Quickly slept in her chair while Henry came out to deliver his speech about the cares of the kingdom. The sick king draped a cloak around his shoulders-a cloak decorated with a map of Britain (first displayed by Glendower in Part 1). In this scene it was clear that Henry, as both an individual and an embodiment of the state, had been destroyed by Richard's prophecy. The frailty of the sleeping woman in the background served as a poignant reminder of how difficult it was for anyone to avoid being destroyed along with these greater forces.

In this world abstractions such as Rumor and Opinion carried special strength as well, since they mattered more than people. For this reason, Rumor's prologue at the beginning of Part 2 held special relevance to this production. The speech was disjunctively presented by Antony Byrne in modern dress, wearing a Rolling Stones tongue $t$-shirt and answering a call on his cell phone. In Twitter fashion, \#rumor and other words appeared on the back screen, providing contemporary "relevance" to this speech. However, the sudden modern turn was not necessary. The rest of the production did such a good job of showing how abstractions matter without requiring that we be hit over the head with its appropriateness to our world as well as the late medieval one.

In keeping with the somber music that opened Part 1 and the "uneasy lies the head" speech by Henry in Part 2, the first appearance that Hal made as Henry the Fifth focused upon the grave concerns of managing a state. Everything from the young king's dress to his walk and speech showed that he had fully adopted the weight and consequent facelessness of the state. The repudiation of Falstaff was thus utterly cold and rehearsed, without any hint of pain or regret. Falstaff, expecting the accustomed improvisation which he and Hal once shared, was utterly shell-shocked. At this moment, Falstaff's ubiquitous power to use language to find his way out of any situation deserted him, and there was thus no doubt that this rejection would break him. The one other character who could have provided hope for the continuation of Falstaff's legacy was the Page Boy, played by a very young actor (Luca Saraceni-Gunner). Throughout Part 2, he provided Falstaff with constant companionship and showed a promising wit, independence, and devilish passion. After Prince John's prediction of imminent war with France, the boy became the ominous focus of the play's final tableau. He took center stage in the spotlight, before he was enclosed in darkness-a clear reminder of the fate of the boys in Henry $V$. 
That autumn in Stratford I saw two other Royal Shakespeare Company (RSC) productions that ended on a similar note. The White Devil concluded with the young prince kicking the dead bodies in front of him and laughing, carrying on the sociopathic personalities of his parents. More similarly to Henry IV, The Shoemaker's Holiday concluded with an armband being tied on the apprentice so that he could take part in the next war. The fact that several RSC productions in 2014 gave this ominous look at the future by focusing on the unfortunate fate of a boy seems an interesting coincidence-perhaps one inspired by the British emphasis in 2014 upon the centennial of World War One's outbreak and the "lost generation." To quote from one of the speeches that this production of Henry IV made especially memorable:

There is a history in all men's lives

Figuring the natures of the times deceased,

The which observed, a man may prophesy,

With a near aim, of the main chance of things

As yet not come to life, who in their seeds

And weak beginning lie intreasured.

If these boys serve as another way to show a prophecy of the future, it is a grim one indeed. Such a focus is not unwarranted when staging Shakespeare's history plays, but it is admittedly sobering. This is why, for the first time in my experience of watching this play onstage, I was thoroughly sad to see Falstaff go.

\section{Production Details}

\section{General}

Title Henry IV Parts I and II

Year 2014

Theater Company Royal Shakespeare Company

Theaters The Barbican (UK)

Start Date 2014-11-24

End Date 2014-01-24

\section{Cast}

KING HENRY IV

PRINCE HENRY

PRINCE JOHN

EARL WESTMORELAND

Sir Walter Blunt
JASPER BRITTON

Alex Hassell

ELLIOT BARNES-WORRELL

YOUSSEF KERKOUR

SIMON THORP 


\begin{tabular}{|c|c|}
\hline Thomas Percy, EARl of Worcester & ANTONY BYRNE \\
\hline HENRY PERCy Hotspur & Trevor White \\
\hline EARL EDMUND MORTIMER & ROBERT GILBERT \\
\hline SCROOP & KEITH OSBORN \\
\hline ARCHIBALD, EARL OF DOUGLAS & SEAN CHAPMAN \\
\hline OWEN GLENDOWER & JOSHUA RICHARDS \\
\hline SIR RICHARD VERNON & JIM HOOPER \\
\hline Poins & SAM MARKS \\
\hline GADSHILL & JONNY GLYNN \\
\hline Рето & MARTIN BASINDALE \\
\hline BARDOLPH & JOSHUA RICHARDS \\
\hline LADY PERCY & JENNIFER KIRBY \\
\hline LADY MORTIMER & NIA GWYNNE \\
\hline Mistress QUICKLY & PAOLA DiONISOTTI \\
\hline CHAMBERLAIN & SIMON YADOO \\
\hline CARRIER & NICHOLAS GERARD-MARTIN \\
\hline TRAVELLER & LEIGH QUINN \\
\hline FRANCIS & ELLIOT BARNES-WORRELL \\
\hline PISTOL & ANTONY BYRNE \\
\hline EARL OF NORTHUMBERLAND & SEAN CHAPMAN \\
\hline SHALLOW & Oliver Ford Davies \\
\hline LORD HASTINGS & NICHOLAS GERARD-MARTIN \\
\hline JOHN COLEVILE & ROBERT GILBERT \\
\hline EARL OF WARWICK & JONNY GLYNN \\
\hline Doll Tearsheet & NIA GWYNNE \\
\hline SILENCE & JIM HOOPER \\
\hline WART & LEIGH QUINN \\
\hline FALSTAFF'S PAGE & LUCA SARACENI-GUNNER \\
\hline LORD CHIEF JUSTICE & SIMON THORP \\
\hline LORD THOMAS MOWBRAY & TREVOR White \\
\hline LORD BARDOLPH & SIMON YADOO \\
\hline
\end{tabular}

\section{Creatives}

$\begin{array}{ll}\text { Director } & \text { Gregory Doran } \\ \text { Set Designer } & \text { StePhen Brimson Lewis } \\ \text { Lighting Designer } & \text { Tim Mitchell } \\ \text { Music } & \text { PAUl ENGLishby } \\ \text { Makeup ARTist } & \text { ShauUna Harrison }\end{array}$

